\title{
Immunohistochemical evaluation of proliferation, apoptosis and steroidogenic enzymes in the ovary of rats with polycystic ovary
}

Leonardo Augusto Lombardi ${ }^{1}$, Ricardo Santos Simões ${ }^{2}$, Carla Cristina Maganhin ${ }^{1}$, Maria Cândida Pinheiro Baracat ${ }^{2}$, Gisela

Rodrigues Silva-Sasso ${ }^{1}$, Rinaldo Florencio-Silva ${ }^{1}$, José Maria Soares JR ${ }^{2}$, Edmund Chada Baracat ${ }^{2}$

${ }^{1}$ Discipline of Histology and Structural Biology, Morphology and Genetics Department at the Federal University of São Paulo - Paulista Medical School - UNIFESP/EPM - São Paulo, SP - Brazil ${ }^{2}$ Discipline of Gynecology, Obstetrics and Gynecology Department, University of São Paulo Medical School - FMUSP - São Paulo, SP - Brazi

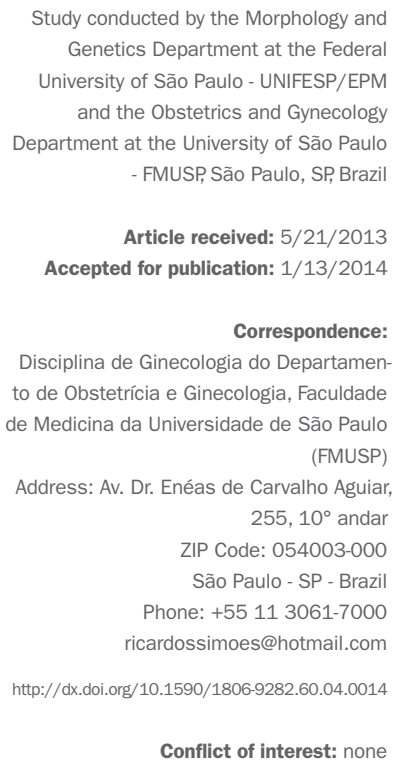

Correspondence: Disciplina de Ginecologia do Departamento de Obstetrícia e Ginecologia, Faculdade de Medicina da Universidade de São Paulo (FMUSP)

Address: Av. Dr. Enéas de Carvalho Aguiar, $255,10^{\circ}$ andar ZIP Code: 054003-000 São Paulo - SP - Brazil Phone: +55 11 3061-7000 ricardossimoes@hotmail.com http://dx.doi.org/10.1590/1806-9282.60.04.0014 Conflict of interest: none

\section{SUMMARY}

Objective: to evaluate the immunohistochemical expression of proliferative, apoptotic and steroidogenic enzyme markers in the ovaries of rats with polycystic ovary syndrome (PCOS).

Methods: twenty rats were divided into two groups: GCtrl - estrous phase, and PCOS - with polycystic ovaries. The GCtrl animals were subjected to a lighting period from 7 am to $7 \mathrm{pm}$, while the animals with PCOS group remained with continuous lighting for 60 days. Subsequently, the animals were anesthetized, the ovaries were removed and fixed in $10 \%$ formaldehyde, prior to paraffin embedding. Sections were stained using H.E. or subjected to immunohistochemical methods for the detection of Ki-67, cleaved caspase-3, CYP11A1, CYP17A1 and CYP19A1. The results were analyzed using Student's t-test $(\mathrm{p}<0,05)$.

Results: morphological results showed evidence of interstitial cells originating from the inner theca cells of degenerating ovarian cysts in PCOS. Immunoexpression of Ki-67 was higher in the granulosa cells in GCtrl, and the theca interna cells in PCOS, while cleaved caspase- 3 was higher in granulosa cells of ovarian cysts from PCOS and in the theca interna cells of GCtrl. Immunoreactivity of CYP11A1 in the theca interna, granulosa and interstitial cells was similar between the two groups, while CYP17A1 and CYP19A1 were higher in the granulosa and interstitial cells in the PCOS group.

Conclusion: the results indicate that the interstitial cells are derived from the theca interna and that enzymatic changes occur in the theca interna and interstitial cells in ovaries of rats with PCOS, responsible for the high levels of androgens and estradiol.

Uniterms: polycystic ovary syndrome, ovary, ovarian cysts, apoptosis, cell proliferation, cytochrome P-450 enzyme eystem, rats, female.

\section{INTRODUCTION}

Polycystic ovary syndrome (PCOS) is a heterogeneous and multifactorial endocrine-metabolic disorder with genetic predisposition that affects $6 \%$ of women of reproductive age. ${ }^{1}$ According to the Rotterdam consensus in 2003, the diagnostic criteria for PCOS include the presence of hyperandrogenism, ovarian cysts on ultrasound and oligoovulation and anovulation. ${ }^{2}$ There is evidence that some genes are responsible for the etiology of this syndrome, including those which codify the enzymes related to an- drogenic metabolism in the ovary. Among them, the CYP11A1, which codifies the P450scc enzyme (CYP11A1) and is present in the internal membrane of the mitochondria converting cholesterol into pregnenolone, and the CYP17A, which codifies the $17 \alpha$-hydroxylase (CYP17A1 or $\mathrm{P} 450 \mathrm{c} 17)$ converting progesterone into androstenedione, which is found in the smooth endoplasmic reticulum, mainly in the theca interna cells. ${ }^{3}$ The CYP19 gene, in turn, contains the sequence that codifies aromatase (P450arom), an enzyme that converts androstenedione 
to estrone, present in granulosa cells. Some authors report that the activity of aromatase is reduced in PCOS, which favors the increase of plasmatic androgens. ${ }^{3,4}$

It is possible to mimic PCOS in rats by inducing continuous light for long periods, so they enter a state of permanent estrus, without ovulation, presence of ovarian cysts, as well as increased circulating estrogens and androgens, as well as insulin resistance. ${ }^{5}$

In previous work we found the presence of ovarian cysts in the ovary of rats submitted to continuous light, the absence of corpora lutea and a large concentration of interstitial cells, which we reported as being derived from theca interna due to the degeneration of ovarian cysts. Moreover, we found a significant increase in serum levels of testosterone and estradiol. ${ }^{6}$ In normal rats or those in permanent estrus, it is reported that androgens come from the interaction of the theca and interstitial (T-I) cells, the latter probably derived from the theca interna. ${ }^{4,7}$ In this work, we propose to investigate the granulosa cells, the theca interna and interstitial cells present in the ovaries of rats in permanent estrus, making a correlation with hormonal levels already evaluated by us in previous work. ${ }^{6}$

Thus, our objective was to evaluate the rates of proliferation (Ki-67), apoptosis (cleaved caspase-3) and CYPS 11A1, 17A1 and 19A1 in ovarian cysts and ovarian interstitial cells of rats with PCOS.

\section{Material AND MEthods}

A prospective experimental study was conducted with 20 adult, virgin rats (Rattus norvegicus albinus) weighing approximately $250 \mathrm{~g}$, provided by the Experimentation Models Development Center (CEDEME) at the Paulista Medical School, Federal University of São Paulo (UNIFESP/ EPM). This study was initially approved by the Research Ethics Committee at UNIFESP/EPM (Report No. 1724/10), following the guidelines of the Canadian Council on Animal Care. ${ }^{8}$

After an adaptation period to the new environment of seven days, all animals were subjected to daily collection of vaginal secretions for seven consecutive days in order to evaluate ovarian function. Only rats with regular estrous cycles were included in the study. Thus, 20 rats were randomly divided into two groups with 10 animals in each group, namely GCtrl - animals in the physiological estrus phase and PCOS - animals with polycystic ovaries.

To obtain animals with polycystic ovaries, the rats were placed in wooden boxes, kept in a vivarium under continuous artificial lighting using lamps (Philips, Daylight Model, 40W) that provided about 400 lux in the region occupied by the rats over a period of 60 consecutive days. The GCtrl animals remained in the same standard vivarium conditions, however, with the lighting period from 7 am to $7 \mathrm{pm}$.

After 60 days, cervical cytology tests were performed again for seven days, in order to identify the phases of the estrous cycle. Thus, from the animals belonging to GCtrl the rats that were cycling and estrous phase were used; while from those being subjected to continuous light those presenting permanent estrus during the entire period of vaginal smears were used.

Subsequently, the animals were anesthetized with 15 $\mathrm{mg} / \mathrm{kg}$ xylazine (Rompun ${ }^{\circledR}, \mathrm{SP}$, Brazil) associated with 30 $\mathrm{mg} / \mathrm{kg}$ ketamine (Ketalar ${ }^{\circledR}$, SP, Brazil) intraperitoneally and placed in a supine position. Next, a longitudinal median incision was made to the abdomen, with the ovaries removed and immediately immersed in 10\% formaldehyde (PBS $10 \mathrm{mM}, \mathrm{pH}$ 7.4) for subsequent histological processing and paraffin embedding. $5 \mu \mathrm{m}$ sections were obtained from the blocks, collected on histological slides and subsequently stained with hematoxylin and eosin (HE) and others destined for immunohistochemical methods.

At the end of the removal of the ovaries, the animals were euthanized by deepening the plane of anesthesia and disposed of in accordance with current standards at the Paulista School of Medicine (UNIFESP/EPM).

\section{Immunohistochemical analysis}

The expression of anti-Ki-67, anti-cleaved caspase-3, anti-CYP11A1, anti-CYP17A1 and anti-CYP19A1 antigens was examined in histological paraffin sections. For that, sections measuring $5 \mu \mathrm{m}$ in thickness were collected on silanized slides and subsequently dewaxed in xylene and hydrated in decreasing concentrations of ethanol. The endogenous peroxidase activity was blocked by incubating the sections with $3 \%$ hydrogen peroxide for 5 minutes. The sections were incubated in a sodium citrate buffer ( $\mathrm{pH}$ 6.0), $10 \mathrm{mM}$ at $95^{\circ} \mathrm{C}$ for 20 minutes. The non-specific binding sites were blocked with $2 \%$ PBS-BSA for 1 hour. The antibodies used were anti-cleaved caspase-3 (Asp175-antibody \#9661, Cell Signaling Technology, Beverly, USA ), anti-Ki-67 (MIB-5, Dako, Denmark, United Kingdom), anti-CYP11A1, anti-CYP17A1 and anti-CYP19A1 (Santa Cruz Biotechnology Inc, USA). The secondary antibody used in all cases was biotinylated goat anti-mouse/rabbit (Ig, Duet kit Dako). The reactions were revealed with the streptavidin-peroxidase system (Dako Cytomation, USA) using 3,3'- diamino- 
benzidine $(\mathrm{DAB})$ as a chromogen. The sections were subsequently counter-stained with hematoxylin. As a negative control incubated sections incubated with non-specific immunoglobulin (DAKO Cytomation, USA) were used in place of the primary antibody.

\section{Morphometric analysis}

The evaluation of the slides was performed at the histology service at UNIFESP/EPM. To quantify the parameters analyzed, the images were captured by a high resolution camera (AxioCam-MCR, Carl Zeiss) adapted to a light microscope (Axiolab, Carl Zeiss) with a 40X lenses, which were transmitted to a computer with AxioVision Rel 4.2 software (Carl Zeiss). For immunohistochemical evaluation of CYPS 11A1, 17A1 and 19A1, we used semi-quantitative scoring analysis $(\mathrm{H})$ as described by Lessey et al. ${ }^{9}$ and validated in our laboratory, ${ }^{10,11}$ i.e. 0 for negative reactivity and 1 to 3 according to the degree of intensity of reactivity to CYPS. The expression of anti-Ki-67 and anti-cleaved caspase- 3 antigens was determined as a percentage (\%) of positively stained cells, with at least 500 cells counted per animal in all cases.

\section{Statistical analysis}

The values of morphometric and immunohistochemical data were analyzed using an unpaired Student's t test. The rejection level for the null hypothesis was set at 5\% $(\mathrm{p}<0.05)$, indicating significant values with an asterisk.

\section{Results}

The colpocytologic smear showed that all animals subjected to continuous light stopped cycling and remained in persistent estrus, while the animals in the control group had normal estrous cycles (4-5 days), and were anesthetized as they entered the estrus stage.

The morphological results showed the presence of numerous follicles in different stages of development in the ovary in the physiological estrus phase (GCtrl), some interstitial cells forming cords and various whole or degenerating corpora lutea. In the polycystic ovaries group (PCOS), we noted the same architecture observed in GCtrl, without the presence of corpora lutea. However, we noted the presence of numerous ovarian cysts, and folded contact between the granulosa cells and the theca interna (Figures $1 \mathrm{~A}$ and $\mathrm{B}$ ). In the ovarian stroma of the PCOS group, between the cysts and follicles we identified the presence of numerous arrangements of cells with epithelioid appearance, containing bulky and very evident nucleoli, forming spherical or cor- dlike structures, typical characteristics of the interstitial cells. The appearance of cysts containing granulosa cell in apoptosis and theca interna cells with mitotic figures is common. We noticed some cysts formed only by theca interna cells due to disintegration of granulosa cells, some of which appear to be collapsing and forming cords of interstitial cells. The presence of numerous ovarian cysts and large concentration of interstitial cells are indicative of polycystic ovary syndrome (Figures 1C and D).

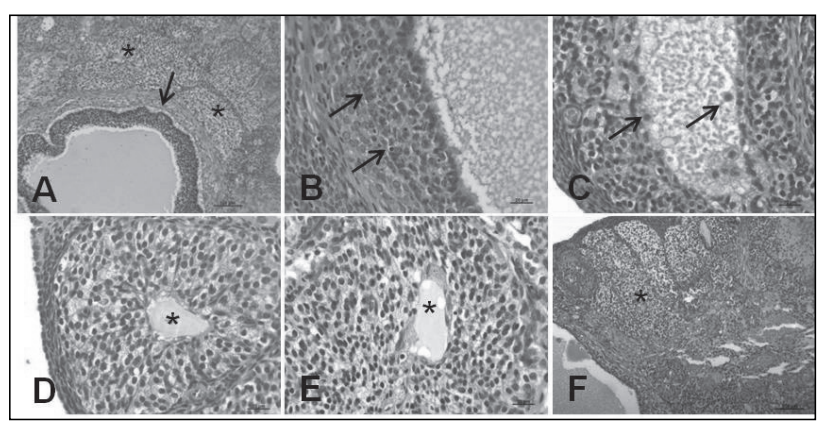

FIGURE 1 Photomicrographs of regions of ovaries belonging to the group of rats suffering from polycystic ovary syndrome (PCOS). Note part A of an ovarian cyst showing folding of the wall (arrow) and numerous interstitial stromal cells $\left(^{*}\right)$. In region $B$ there is contact between the granulosa cells and theca interna (arrows). In C, the interior of the cyst showing some granulosa cells still intact (arrows) with the wall formed by theca interna cells $\left({ }^{*}\right)$. In D and $\mathrm{E}$ note the cysts formed by cells of the theca interna alone, containing eosinophilic material inside $\left({ }^{*}\right)$, and in $\mathrm{F}$, at a minor increase we can observe a high concentration of interstitial cells in the ovarian stroma $\left({ }^{*}\right)$. H.E. Figures A and F 100X; B,C,D and E 400X.

The immunohistochemical results are shown in Table 1 and in Figure 2 (A, B and C). We noted that the percentage of cellular proliferation was significantly higher in granulosa cells of the antral follicles in the Ctrl group compared to the granulosa cells of ovarian cysts present in the PCOS group. The percentage of cellular proliferation was higher in the theca interna in the PCOS group. The percentage of apoptosis was significantly higher in granulosa cells and lower in the theca interna in the PCOS group. In relation to CYPS, we noted intense reactivity to CYP11A1 in the interstitial cells and theca interna cells, both in the Ctrl and PCOS group. In the control group we also observed reactivity in the corpora lutea. We obtained higher immunoreactivity scores to CYP17A1 and CY19A1 both in granulosa and interstitial cells in the PCOS group (Table 1). 


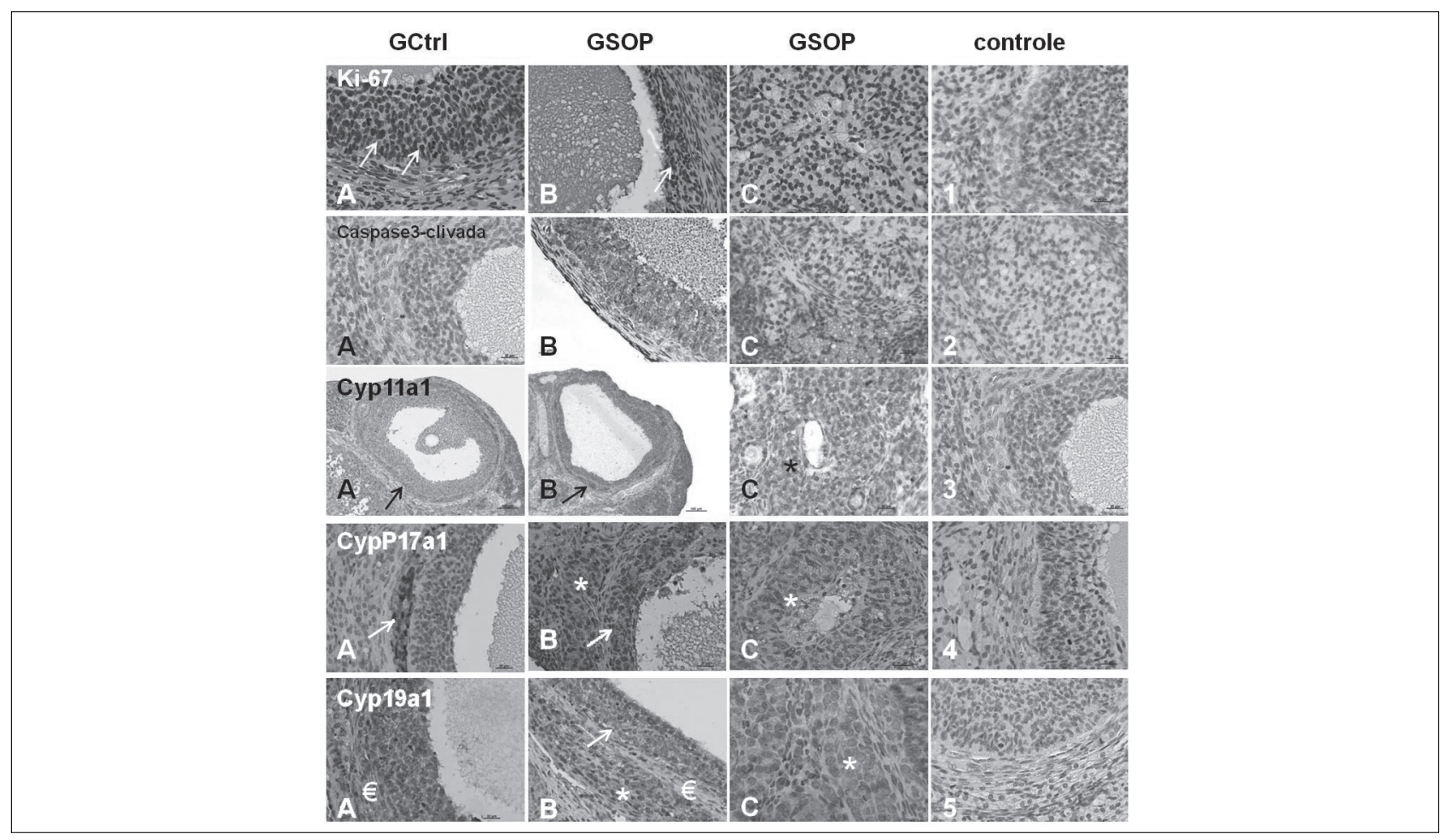

FIGURE 2 Photomicrographs of regions of ovaries in female rats belonging to the control (Ctrl) and polycystic ovary syndrome (PCOS) groups. Note in A of the control group for Ki-67 and in B reaction for cleaved caspase-3 there is intense reactivity in granulosa cells (arrows). We observed no reactivity to $\mathrm{Ki}-67$ in interstitial cells in both groups $(\mathrm{C})$. The theca interna (arrows) and interstitial cells $\left({ }^{*}\right)$ were reactive to CYPS11A1 and CYPS17A1 both in the Ctrl (A) and PCOS group (B). In relation to CYP19A1 we noted the absence of reaction in the theca interna $(€)$ and intense reactivity in granulosa and interstitial cells in the PCOS group. Numbers 1 to 5 represent the negative controls of the respective reactions.

TABLE 1 Means and standard deviations $(M \pm D P)$ from the immunohistochemical detection of various parameters obtained from mature ovarian follicles (theca interna and follicular cells) from the control group (GCtrl) and in the ovarian cysts of the polycystic ovary group (PCOS), as well as interstitial cells

\begin{tabular}{l|l|l|l} 
Antibody & Structure & GCtrl & GPCOS \\
\hline Ki-67 (\%) & Theca interna & $1.01 \pm 0.12$ & $2.50 \pm 0.22^{*}$ \\
& Granulosa cells & $95.05 \pm 0.02$ & $1.50 \pm 0.02^{*}$ \\
& Interstitial cells & $0.00 \pm 0.00$ & $0.00 \pm 0.00$ \\
\hline Cleaved caspase-3 (\%) & Theca interna & $0.17 \pm 0.01$ & $0.01 \pm 0.01^{*}$ \\
& Granulosa cells & $1.50 \pm 0.01$ & $89.10 \pm 7.72^{*}$ \\
& Interstitial cells & $0.15 \pm 0.05$ & $0.10 \pm 0.10$ \\
\hline CYP11A1 (score) & Theca interna & $3.00 \pm 0.01$ & $3.00 \pm 0.02$ \\
& Granulosa cells & $0.10 \pm 0.06$ & $0.10 \pm 0.02$ \\
& Interstitial cells & $3.00 \pm 0.01$ & $3.00 \pm 0.01$ \\
\hline CYP17A1 (score) & Theca interna & $2.90 \pm 0.01$ & $2.92 \pm 0.04$ \\
& Granulosa cells & $0.10 \pm 0.06$ & $1.50 \pm 0.02^{*}$ \\
& Interstitial cells & $0.30 \pm 0.02$ & $2.50 \pm 0.01^{*}$ \\
\hline CYP19A1 (score) & Theca interna & $0.05 \pm 0.01$ & $0.07 \pm 0.02$ \\
& Granulosa cells & $1.90 \pm 0.10$ & $2.80 \pm 0.15^{*}$ \\
& Interstitial cells & $0.15 \pm 0.02$ & $0.45 \pm 0.04^{*}$ \\
\hline
\end{tabular}

${ }^{*} p<0.05$ 


\section{Discussion}

Polycystic ovary syndrome has been considered as one of the most controversial entities in gynecological endocrinology, as it includes a wide spectrum of clinical signs and symptoms. ${ }^{1}$ The heterogeneity of this syndrome has led to the creation of numerous discussions and varying consensuses for diagnosis. However, its pathophysiology is not yet fully understood. ${ }^{2}$ In an extensive literature review, Prapas et al. ${ }^{12}$ reported that numerous genetic factors were involved in polycystic ovary syndrome. They found a wide range of changes in genes related to various signal transduction pathways, such as in steroidogenesis, the action of steroid hormones, action and regulation of gonadotropin, action and secretion of insulin, homeostasis and chronic inflammation, showing a disease with multiple complexity, which can display numerous variables.

Numerous experimental models have been developed to study polycystic ovary syndrome including the continuous light, which Mahajan ${ }^{13}$ reports as being superior to others for studying the pathophysiology of polycystic ovaries, as it is not an invasive method. However, we believe that this model may represent only one of the phenotypes of the syndrome. Thus, to obtain polycystic ovaries we relied on the methodology of Lombardi et al., ${ }^{6}$ submitting rats to constant lighting at 400 lux for a period of 60 consecutive days to induce the state of persistent estrus, during which they reported the presence of numerous ovarian cysts, one of the characteristics of polycystic ovary syndrome.

It is important to reiterate that the physiological and behavioral processes that exhibit circadian rhythms are controlled by endogenous "clocks" present in the neurons of the suprachiasmatic nucleus of the hypothalamus (SCN) and in some cells of peripheral tissues. ${ }^{14}$ These cell clocks are triggered by molecular changes that alter the rhythmic expression of genes with a frequency of around 24 hours. The molecules that cause these changes consist of compounds which interact with a positive or negative effect on transcriptional/translational feedback, in which heterodimers that activate transcription are present and thus promote the transcription of genes (CRY1 and CRY2) ${ }^{14}$ SCN neurons receive information daily about light and darkness in the environment through a monosynaptic neural pathway originating from a subset of the light sensitive ganglion cells present in the retina. ${ }^{15,16}$ The SNC, in turn, synchronizes the physiology of the organism with daily changes, coordinating tissue-specific activities owing to neural and humoral oscillations.
Thus, the biological "clock" present in the SCN plays an important role in regulating the reproductive cycle in $\mathrm{fe}$ males, ${ }^{17}$ since neuronal projections from these centers to neurons that secrete GnRH have been described in rats. ${ }^{18}$

Our morphological results showed that the ovaries of all animals subjected to continuous light contained the presence of numerous ovarian cysts, a large amount of interstitial cells and absence of corpora lutea. In the PCOS group we noted granulosa cell apoptosis in ovarian cysts, as well as images that indicate that theca interna cells remained intact and formed cysts that subsequently form the cords of interstitial cells. These findings, as mentioned earlier, are indicative of polycystic ovary syndrome, as one of the phenotypes described in the ovaries of women based on the criteria of the ESHRE/ASRM (2003) and the AE-PCOS Society. ${ }^{2}$

In a previous study we reported a significant increase in the amount and nuclear volume of interstitial cells in female rats kept under continuous light, which would result in increased activity of these cells. ${ }^{6}$ Soares et al. ${ }^{7}$ described the ultrastructure of interstitial cells in the ovaries of rats with polycystic ovaries induced by pinealectomy, as cells with epithelial characteristics with a high concentration of cytoplasmic organelles, especially mitochondria and smooth endoplasmic reticulum, as well as voluminous nucleus and evident nucleolus, typical characteristics of steroid-secreting cells. In the ovaries of rats in physiological estrus, they reported interstitial fibroblast-like cells with fusiform format.

Rzepczynska et al., ${ }^{19}$ in a study addressing species reactive to oxygen, indicate that the growth regulation of theca-interstitial cells in rats is essential for normal ovarian follicle development, as well as its function. The authors report that antioxidants are involved in the modulation of signal transduction pathways, including the regulation of growth, inducing apoptosis in mesenchymal cells and interstitial cells of the ovary. They also make a correlation of clinical and translational significance, supporting the use of antioxidants in the treatment of PCOS, a condition associated with excessive growth in the activity of interstitial cells.

Our immunohistochemical findings showed that there was low percentage of cell proliferation in granulosa cells in PCOS group, with the rate of cell proliferation in the theca interna higher in the PCOS group compared to the GCtrl. The reactivity of cleaved caspase-3 showed intense programmed cell death (apoptosis) in granulosa cells in the ovarian cysts of the PCOS group, while remaining low in the theca interna. We did not identify in im- 
munohistochemical reactivity to Ki-67 in the interstitial cells, which shows they must be derived from another cell type. Our data supports the findings of Galas et al., ${ }^{20}$ who describe interstitial cells as being derived from cells that have broken off due to the intense proliferation of the theca interna, which are specialized in the production of androgens, thus perpetuating the hyperandrogenic state. In the sections stained with H.E. we noted in the ovarian stroma of the PCOS group the presence of a high concentration of interstitial cells in the form of cysts or cords. Based on our morphological and immunohistochemical findings we believe that the theca interna cells of the cysts, where granulosa cells enter apoptosis, would remain intact and maintain the vesicular formation would decrease in size. These later form cellular cords, denominated as interstitial cells.

As the cell proliferation rate is higher in the theca interna in the PCOS group and apoptosis of interstitial cells in GCtrl group, this fact would facilitate the accumulation of interstitial cells in ovarian stroma, which could explain, at least in part, the maintenance of a static state, leading to the persistence of large concentrations of interstitial cells in the ovaries and the high hormone levels related to this syndrome. ${ }^{6}$

In their study, Sun et al..$^{21}$ observed relatively low positivity in granulosa cells and theca interna using the TUNEL assay (apoptosis/necrosis) and PCNA (proliferation) in ovarian cysts in pigs, stating that the cellular proliferation/apoptosis system in ovarian cysts would be changed. Salvetti et al., 22 in turn, studied the proliferation, apoptosis, and some proteins involved (Bax, Bcl-xL, Bcl-w and $\mathrm{Bcl}-2$ ) in various types of ovarian follicles in rats and reported that the low apoptosis observed in rats with PCOS is responsible for the maintenance of ovarian cysts. They make no mention of the interstitial cells, however.

The synthesis of steroid hormones is characteristic of some cells in the body that contain the necessary enzymes for the production of these hormones, and are present in the ovarian theca interna and granulosa cells. ${ }^{8}$ The synthesis reaction of steroids depends on a cytochrome P450 enzyme system, formed by several enzymes found throughout the phylogenetic spectrum, from bacteria to animals. It begins in the inner membrane of mitochondria, where a side-chain cleavage enzyme (P450scc or CYP11A1) converts cholesterol to pregnenolone. ${ }^{3}$ In rats, the main source of cholesterol comes from blood capillaries where high density lipoproteins (HDLs) are captured via B1 receptors (SR-B1) and low density lipoproteins (LDL) mediated by endocytosis receptors (LDL receptors). In humans the main source of cholesterol is receptor-mediated endocytosis. ${ }^{3}$ In our material, we observed virtually the same reactivity to CYP11A1 in theca interna cells and in interstitial cells in both the Ctrl and PCOS groups, though the Ctrl also showed reactivity in the corpora lutea.

In our previous study, the high serum levels observed in animals in the PCOS group were probably due to the intense expression of CYP17A1 enzyme present in the theca interna and interstitial cells. ${ }^{6}$ This enzyme located in the smooth endoplasmic reticulum is related to androgen production, as it converts pregnenolone and progesterone, formed in the mitochondria into dehydroepiandrosterone (DHEA) and androstenedione. ${ }^{4}$ Among the numerous causes hyperandrogenism it is considered a key factor in the origin and maintenance of the changes that occur in women with PCOS..$^{23}$ In our material, the reactivity of CYP17A1 in the control group was very weak in granulosa cells, and more pronounced in theca interna cells. It is believed that the theca interna cells that produce androgens act in a paracrine manner in granulosa cells. ${ }^{24}$ Another function would be to modulate the signaling of follicle stimulating hormone (FSH) through the androgen receptors (ARs) in granulosa cells to amplify the cAMP concentration. Thus, the constant stimulation of androgens induces changes in ARs or even induces epigenetic changes, leading to ovarian dysfunction in PCOS. ${ }^{24}$

In relation estradiol in a previous study we also obtained higher levels on PCOS group, results which meet the current immunohistochemical findings, given that the CYP1A1 enzyme that catalyzes the formation of estrogens from androgens showed greater reactivity in the PCOS group. CYP19A1 (aromatase) is normally present in granulosa cells, whereas in ovaries belonging to the PCOS group we found both immunoreactivity in granulosa cells and in the interstitial cells, which may explain the increase in estrogens. This enzyme is located in the smooth endoplasmic reticulum and can be found in numerous tissues such as ovaries, blood vessels, bones, adipose tissue and liver. ${ }^{25}$ Nevertheless, immunohistochemical findings support the hormonal data obtained by us previously and, furthermore, are in accordance with those observed by Lin et al. ${ }^{26}$ in rats with polycystic ovaries obtained by injection of testosterone (DHEA), where there was increase in serum levels of estradiol and testosterone, with no change in progesterone levels.

During the menstrual cycle the sharp increase in serum levels of estradiol in the proliferative phase, which occurs due to the recruitment of ovarian follicles, stimulates the release of luteinizing hormone $(\mathrm{LH})$ from the 
pituitary gland, which culminates with ovulation. However, if serum levels remain constant, LH is not released. ${ }^{27}$ Our results indicate that rats subjected to continuous light show no ovulation, probably due to the high levels of estradiol and testosterone produced mainly by interstitial cells, leading to lack of control in the hypothalamic region with inhibition of pituitary function.

\section{Conclusion}

Morphological and immunohistochemical analyses showed strong evidence that the interstitial cells are derived from the theca interna of ovarian cysts and also have high concentration of enzymes involved in the production of testosterone and estradiol, which may explain the high serum levels of these hormones present in rats with polycystic ovary syndrome.

\section{FINANCIAL SUPPORT}

Scholarship from the National Council for Scientific and Technological Development (CNPq) for the student Leonardo Augusto Lombardi.

\section{Resumo}

Avaliação imunoistoquímica de proliferação, apoptose e enzimas esteroidogênicas no ovário de ratas com síndrome dos ovários policísticos.

Objetivo: avaliar a expressão imunoistoquímica de marcadores de proliferação, apoptose e enzimas esteroidogênicas nos ovários de ratas com síndrome dos ovários policísticos (SOP).

Métodos: vinte ratas foram divididas em dois grupos: controle (GCtrl), na fase de estro, e com síndrome dos ovários policísticos (GSOP). Os animais do GCtrl permaneceram com período de luz das 7 às 19 horas, e os do GSOP com iluminação contínua, durante 60 dias. Posteriormente, os animais foram anestesiados, os ovários removidos e fixados em formol a $10 \%$ para inclusão em parafina. Cortes histológicos foram corados pelo H.E. e outros submetidos a métodos imunoistoquímicos para detecção de Ki-67, caspase 3 clivada, CYP11A1, CYP17A1 e CYP19A1. Os resultados foram submetidos ao teste $t$ de Student $(\mathrm{p}<0,05)$.

Resultados: a morfologia mostrou evidências da origem das células intersticiais a partir das células da teca interna dos cistos ovarianos em degeneração no GSOP. A imunoexpressão do Ki-67 mostrou-se aumentada nas células da granulosa no GCtrl e na teca interna do GSOP, enquanto a caspase 3 clivada se mostrou aumentada nas células da granulosa dos cistos ovarianos do GSOP e na teca interna do GCtrl. A imunorreatividade da CYP11A1 nas células da teca interna, bem como da granulosa e intersticiais, mostrou-se semelhante entre os dois grupos. As CYP17A1 e CYP19A1 apresentaram-se aumentadas nas células da granulosa e intersticiais no grupo SOP.

Conclusão: os resultados indicam que as células intersticiais são oriundas da teca interna e que ocorrem alterações enzimáticas nas células da teca interna e intersticiais do ovário de ratas com SOP, responsáveis pelos altos níveis de androgênios e de estradiol.

Unitermos: síndrome do ovário policístico; ovário; cistos ovarianos; apoptose; proliferação celular; sistema enzimático do citocromo P-450; ratos; feminino.

\section{References}

1. Batista JG, Soares-Jr JM, Maganhin CC, Simões RS, Tomaz G, Baracat EC. Assessing the benefits of rosiglitazone in women with polycystic ovary syndrome through its effects on insulin-like growth factor 1 , insulin-like growth factor-binding protein-3 and insulin resistance: a pilot study. Clinics (São Paulo). 2012;67(3):283-7.

2. Azziz R, Carmina E, Dewailly D, Diamanti-Kandarakis E, Escobar-Morreale HF, Futterweit W, et al. The Androgen Excess and PCOS Society criteria for the polycystic ovary syndrome: the complete task force report. Fertil Steril. 2009;91(2):456-88.

3. Miller WL. Steroid hormone synthesis in mitochondria. Mol Cell Endocrinol. 2013;379(1-2):62-73.

4. Ortega I, Cress AB, Wong DH, Villanueva JA, Sokalska A, Moeller BC, et al. Simvastatin reduces steroidogenesis by inhibiting CYP17A1 gene expression in rat ovarian theca-interstitial cells. Biol Reprod. 2012;86(1):1-9.

5. Sara L, Antal P, Masszi G, Buday A, Horvath EM, Hamar P, et al. Arteriolar insulin resistance in a rat model of polycystic ovary syndrome. Fertil Steril. 2012;97(2):462-8.

6. Lombardi LA, Simões RS, Maganhin CC, Silva CF, Maciel GA, Baracat EC, et al. Morphology of the interstitial cells of rat polycystic ovaries: an experimental study. Rev Bras Ginecol Obstet. 2012;34(7):323-8.

7. Soares Jr JM, Simões MJ, Oshima CT, Mora OA, De Lima GR, Baracat EC. Pinealectomy changes rat ovarian interstitial cell morphology and decreases progesterone receptor expression. Gynecol Endocrinol. 2003;17(2):115-23.

8. Olfert ED, Cross BM, McWilliam AA, editors. Guide to the care and use of experimental animals. $2^{\text {nd }}$ ed. Ottawa: Canadian Council on Animal Care; 1993.

9. Lessey BA, Killam AP, Metzger DA, Haney AF, Greene GL, McCarty KS. Immunohistochemical analysis of human uterine estrogen and progesterone receptors throughout the menstrual cycle. J Clin Endocrinol Metab. 1988;67(2):334-9.

10. Carbonel AA, Baracat MC, Simões RS, Simões MJ, Baracat EC, Soares Jr JM The soybean concentrated extract proliferates the vagina of adult rats. Menopause. 2011;18(1):93-101.

11. Panzan MQ, Mattar R, Maganhin CC, Simões RS, Rossi AG, Motta EL, et al. Evaluation of FAS and caspase- 3 in the endometrial tissue of patients with idiopathic infertility and recurrent pregnancy loss. Eur J Obstet Gynecol Reprod Biol. 2013;167(1):47-52.

12. Prapas N, Karkanaki A, Prapas I, Kalogiannidis I, Katsikis I, Panidis D. Genetics of polycystic ovary syndrome. Hippokratia. 2009;13(4):216-23.

13. Mahajan DK. Polycystic ovarian disease: animal models. Endocrinol Metab Clin North Am. 1988;17(4):705-32.

14. Cagampang FR, Bruce KD. The role of the circadian clock system in nutrition and metabolism. Br J Nutr. 2012;8(1):1-12.

15. Hannibal J, Fahrenkrug J. Melanopsin: a novel photopigment involved in the photoentrainment of the brain's biological clock? Ann Med. 2002;34(5):401-7.

16. Galindo-Romero C, Jiménez-López M, García-Ayuso D, Salinas-Navarro M, Nadal-Nicolás FM, Agudo-Barriuso M, et al. Number and spatial distribution of intrinsically photosensitive retinal ganglion cells in the adult albino rat. Exp Eye Res. 2013;108:84-93. 
17. De La Iglesia HO, Schwartz WJ. Minireview: timely ovulation: circadian regulation of the female hypothalamo-pituitary-gonadal axis. Endocrinology. 2006;147(3):1148-53.

18. Kalsbeek A, Buijs RM. Output pathways of the mammalian suprachiasmatic nucleus: coding circadian time by transmitter selection and specific targeting. Cell Tissue Res. 2002;309(1):109-18.

19. Rzepczynska IJ, Foyouzi N, Piotrowski PC, Celik-Ozenci C, Cress A, Duleba AJ. Antioxidants induce apoptosis of rat ovarian theca-interstitial cells. Biol Reprod. 2011;84(1):162-6

20. Galas J, Starowicz A, Knapczyk-Stwora K, Tabarowski Z, Szołtys M. Steroid concentrations and immunoexpression of steroidogenic enzymes in ovaries of aged bank voles: effect of photoperiod. J Exp Zool A Ecol Genet Physiol. 2012;317(10):622-9.

21. Sun YL, Zhang J, Ping ZG, Wang CQ, Sun YF, Chen L, et al. Relationship between apoptosis and proliferation in granulosa and theca cells of cystic follicles in sows. Reprod Domest Anim. 2012;47(4):601-8.

22. Salvetti NR, Panzani CG, Gimeno EJ, Neme LG, Alfaro NS, Ortega HH. An imbalance between apoptosis and proliferation contributes to follicular persistence in polycystic ovaries in rats. Reprod Biol Endocrinol. 2009;7:68.
23. Maliqueo M, Sun M, Johansson J, Benrick A, Labrie F, Svensson H, et al. Continuous administration of a $\mathrm{P} 450$ aromatase inhibitor induces polycystic ovary syndrome with a metabolic and endocrine phenotype in female rats at adult age. Endocrinol. 2013;154(1):434-45

24. Qu F, Wang FF, Yin R, Ding GL, El-Prince M, Gao Q, et al. A molecular mechanism underlying ovarian dysfunction of polycystic ovary syndrome: hyperandrogenism induces epigenetic alterations in the granulosa cells. J Mol Med (Berl). 2012;90(8):911-23.

25. Rumianowski B, Adler G, Safranow K, Brodowska A, Karakiewicz B, Słuczanowska-Głabowska S, et al. CYP17 and CYP19 genetic variants are not associated with age at natural menopause in Polish women. Reprod Biol. 2012;12(4):368-73

26. Lin W, Song ZJ, Sun WM, Dong L, Jin KK, Wang WT, et al. Expression of steroidogenic enzymes in the rat model of polycystic ovary syndrome. Sheng Li Xue Bao. 2013; 65(2):171-7.

27. Marci R, Graziano A, Lo Monte G, Piva I, Soave I, Marra E, et al. GnRH antagonists in assisted reproductive techniques: a review on the Italian experience. Eur Rev Med Pharmacol Sci. 2013;17(7):853-73. 